\title{
Text me! Interpersonal Discourse Analysis of Egyptian Mobile Operators' SMSs
}

\author{
Mai Samir El-Falaky \\ Arab Academy for Science and Technology, College of Language and Communication, Egypt \\ E-mail: maismf@hotmail.com
}

Doi:10.7575/aiac.alls.v.7n.1p.11

URL: http://dx.doi.org/10.7575/aiac.alls.v.7n.1p.11
Received: 23/08/2015

Accepted: 28/10/2015

\begin{abstract}
The present study examines the discourse of a number of Short Messaging Service (SMS). The selected data is analyzed according to the lexico-grammatical choices reflected in the interpersonal metafunction. Results are, then, interpreted for the purpose of deciding how service providers use language to convince a large number of customers of their digital products. Such accomplishment is conditioned by how much they succeed in persuading their audience that they are capable of providing them useful products and how these products, in turn, meet their communicative demands. The study assure that the selection of the lexico-grammatical tools is crucial in enabling senders to perform a number of functions such as constructing social relations, exercising power or maintaining solidarity with the receivers.
\end{abstract}

Keywords: service provider, mood, pronouns, tense, discourse, lexico-grammatical

\section{Introduction}

As a result of the breakthrough of modern telecommunication, people have become closer and opened to all aspects of life. Convincing and influencing people become difficult as they have the choice to see, compare, and deicide. People have a wide range of choices where they can opt for one and discard hundred of others.

All aspects of language are supposed to be studied when it comes to analyzing any type of discourse. Although language is an integral element in communication it is not the main goal. It gains its importance, only, from the surrounding conditions and circumstances. Wodak (2002) argues, "Language is not powerful on its own. It gains power by the use powerful people make of it" (p. 10). In the context of this study, the discourse of SMS is investigated due to the phenomenal of such means of communication since the late 1990s (Ling, 2004)

\section{Discourse: definition and overview}

Discourse, as defined by van Dijk (1997a), is perceived as a practical, social and cultural phenomenon. According to van Dijk, discursive language is composed of more than a series of words or clauses and sentences. It is a "...sequence of mutually related acts" (p.3). As they are acts, hence, discourses suggest members of some kind. Thus, language users are not only speakers, writers or listeners, they are also members of social institutions and social categories, professions, organizations, or communities. Being such members they have the ability to construct and display their social roles and identities by the language they use.

\subsection{Discourse analysis}

An agreed upon definition of 'Discourse Analysis' is that which regards it as "the practice of analyzing empirical raw material and information as discursive forms" (Howarth and Stavrakakis, 2000. p.4). It is, generally, "taken to be the analysis of 'texts' in a broad sense - written texts, spoken interaction, the multimedia texts of television and the Internet, etc" (Fairclough, 2005, p.916). This, as Fairclough (2005) claims, means that discourse analysis is interested in a wide range of linguistic data such as speeches, reported interviews, debates and others as long as they constitute a discourse and its reality.

van Dijk (1997a) manifests the importance of discourse analysis as being studied "not only as a form, meaning and mental process, but also as complex structures of interaction and social practice and their functions in context, society and culture" (p.7). This kind of interaction, as proposed by van Dijk, is intentional, controlled and purposeful that aim at communicating acts.

Based on van Dijk's approach to discourse analysis, Butler (2003) views some of the principles that discourse study should adopt. He claims that the study of discourse must deal with authentic, naturally occurring data. It must also recognize the dynamic nature of discourse. Participants, as Butler argues, act as members of particular social and cultural groupings and not only elements of the discourse. More importantly, the study of discourse must describe the functional and semantic relationships between its units.

Ultimately, researchers agree to use discourse analysis as a methodological tool, as it is an essential part of the social practices. They reach a conclusion that every text is influencing and at the same time influenced by its social context. 


\subsection{Computer-mediated discourse}

There is no wonder that technology has influenced the way we communicate. Communication in this sense involves more than exchanging information. Rather, the technological inventions builds several types of discourses that reflects our cultural worlds, our power relations and our ideological backgrounds.

An agreed upon definition of computer-mediated discourse (CMD) is that form of communication between two or more participants where computer, or the like, is medium of communication. That is "any mediation involved in carrying on common, everyday discourses" (Scollon, 1998, p.6).

Ling (2014) stresses the importance of Computer mediated discourse analysis (CMDA). According to Ling such approach "is focused on language and language use; it is also a set of methods (a toolkit) grounded in linguistic discourse analysis for mining networked communication for patterns of structure and meaning, broadly construed".(p.1)

The discourse of text messages includes expressive language that suits various forms of communication. Further more text messaging has influential role of affecting the society Ling (2004) claims that "texting has been credited with assisting in the coordination of social movements, such as the revolt against Philippine President" (Ling, 2004).

It is obvious that many institutions may make use of CMC to gain greater bargaining power in the influential role in developing interpersonal relations between the company and the current or prospective clients. "As people become more skilled at using CMC to form and maintain relationships, they will use the media more often and use it to communicate in new ways, such as negotiation." (Cronin, 2007, p.13). So no wonder if CMC is used by mobile operators or its marketing personnel. The outcome is expected to be influential especially if the company succeeds to mange the characteristics of this new media. Influencing others using CMC is a skill that could lead to a lot of benefits, only if properly used.

Despite all the advantages of Computer mediated communication, some see it as a disadvantage. It is considered to be "a channel of communication which allows for only superficial forms of maintenance-related communication" (Moore and Craig, 2010, p.83). However, such disadvantage is overcome by the numerous pros of CMC. Moore and Craig enumerate some of them. CMC can enhance trust between interlocutors, increase relational quality and keeps individuals in touch for a long time either for close or long-distance participants. Thus it can be stated that computer mediate discourse foster creativity and unusual communicative attitudes between interlocutors. "No contemporary treatment of the relationship between discourse and creativity would be complete without consideration of the impact of digital technologies on creative practices and creative products" (Rodney, $2012 \mathrm{p}, 165$ ). Digital discourse, as a type of new media discourse have many forms, emails, online chats, mobile texting, etc. each one has its own features which vary from the other from different perspectives such as time, scale of distribution, size of included message. SMSs is one of the widely spread form of technological means of interaction as it is a rapid form of exchange.

\subsection{The discourse of SMS}

SMS is a global means of communication that enables users to exchange messages instantly. The importance of SMS as a communicative medium lies in the fact that it could include important information within a limited chunk. Frehner (2008) describes SMS as "informative as well as expressive and phatic medium" (p.94)

Herring (2013) stresses on the importance of analyzing various "discourse in these new environments" (p.5). According to Herring text messages has to be investigated from two perspectives: content and language.

The reason why linguists should be interested in the discourse of SMS is ascribe to what Tagg (2012) claims to be the "unlikeliness of it all". According to Tagg, text messages are not just electronic notes. They represent a representation of how technology is used for "expressive or communicative purposes... Seen in the light of a progression of technological and social developments, texting is simply one more means of communication.” (p.2). Tag describes text messaging as unique and irreplaceable.

Segerstad (2006) highlights the importance of SMSs in the fact that "it is monomodal and thus can only take advantage of what cab be conveyed through the single channel of the visible writing system" (p.34)

Herring et.al. (2013) questions the term "computer-mediated communication" as that type of technology does not reflect other forms of communicative means as communicating by mobile phones which is for example is considered "honorary computers where text messaging is concerned" (p.5) according to Herring et. al (2013) terms such as 'digital media' and new media, digital discourse are better used to describe such type of language interactions

\subsection{WHY SMS FOR THIS STUDY?}

Tagg (2012) states that the importance of studying the discourse of SMS lies in its important nature as a communicative means. The study at hand focuses on the analysis of SMSs sent by mobile operators to its customer as this was the initial purpose of SMS. "The text message was initially designed as a way for phone companies to get in touch with consumers rather than for inter-consumer communication" (Tagg, 2012, p.2). Thus the interest in the analysis of the SMS aroused due to the linguistic form of these short messages and how they are able to perform the functions expected from the language use. It can clearly be stated that a lot of interpersonal relations are maintained through such technological discursive form.

Humphreys (2007) also stresses the viability of using mobile phones and it services, among which is SMSs, in the communication process. Humphreys ascribe such importance to the "the increased individuality of the device. Mobile phones seem personal" (p.8). Another reason of the widespread of such means of communication is the nature of the 
developing countries. According to Humphreys"... mobile phone penetration rates for developing countries are significantly lower than rates in developed European.... " (p10). These reasons among other prompt the use of SMSs as an effective means of communication. In fact, such communicative processes, especially when used with the mobile operators has the ability to create and maintain social relations if used properly with the clients.

The study capitalizes on a corpus of SMS because of the importance of such discourse type. It is a rich context of language use. Segerstad (2006) assures this fact by pinpointing its importance in "mediating and maintaining social relationships" (p.50). Thus the study shows how the analysis of the linguistic choices reflects the intermingling between the technological, functional and linguistics elements of discourse.

\section{Research questions}

Using SFG's interpersonal metafunction, the study seeks to answer the following questions:

1. What are the lexico-grammatical tools used by Mobile phones service providers to achieve their targets?

2. How are power relations constructed between the sender and the targeted receivers?

\section{Corpus of the study}

To support its intent, this research capitalizes on a corpus consisting of a total sum of SMSs collected from the three mobile service providers in Egypt, namely, Mobinil, Vodafone, and Etisalat.

Data, comprising 110 short messages, is processed using computer software named UAM CorpusTool. Such tool is used to make annotations to the segmented units so as to facilitate the requested statistics created on the basis of the lexico-grammatical approach. Based on the resulting statistics, a discourse analysis is carried out and analyzed qualitatively.

\section{SFG and the interpersonal metafunction}

Systemic Functional Grammar (SFG) is an approach for analyzing language according to the functions it performs. It analyzes language in terms of: (a) relationships maintained between speakers and their audiences (interpersonal function), (b) how speakers express themselves (experiential function), and (c) how they organize such expressions and feelings in their texts whether spoken or written (textual function). In this study the a corpus of SMS (Short Message service) is analysed to inspect how the communicative process proceeds. The integration between linguistic theoretical theories and 'new discourse' is something seen by many. Assertingly, Spilioti (2011) pinpoints the need of adopting "established theoretical concepts in light of "new" computer-mediated data derived from an array of emerging and volatile cultural setting" (p.67). That is why SFG's interpersonal metafunction is the essential analytical tool adopted in this study.

The interpersonal metafunction is one of the main purposes of communication. Discourse participants aims at interacting with each other so as to establish and maintain appropriate social links. This is related to the fact of exchanging meanings. It is a two-way communication process, i.e., what we say, we say for a purpose.

According to SFG, the most fundamental purposes in any exchange are giving (and taking) or demanding (and being given) a commodity of some kind. This commodity can be information or goods and services. So, we end up with basic speech roles: giving information, demanding information, giving goods and services and demanding goods and services. The usual labels for these functions are statements, questions, and commands.

These basic functions are closely associated with particular structures: statements are mostly naturally expressed by declaratives, questions by interrogatives and commands by imperative clauses. The following sections show how the Mood system is composed of two parts, namely 'mood' and 'residue'

The 'mood' consists of two parts: (a) subject, which is a nominal group, and (b) the finite operator, which is part of a verbal group. Together the subject and finite make up the Mood.

The 'Subject' is the doer of the action. It may be carried out by any nominal group as personal pronoun, noun clause, etc. The 'Finite' is one of a small number of verbal operators expressing tense (be, have, and do plus 'be' as the marker of passive voice) and modality as (can, may, could, etc.).

The type of Mood can be indicated by the order in which the subject and Finite are represented. Halliday (1994) proposes a number of cases by which we can assign the type of Mood.

As mentioned above, Mood is seen as a combination of Subject and Finite forming one constituent. It is the remainder of the clause that Halliday has called 'Residue'. According to Halliday (1994) there are three kinds of functional elements in the Residue: 'Predicator', 'Complement', and 'Adjunct'. There can be only one predicator, one or two complements and an indefinite number of adjuncts up to about seven.

The predicator is realized by a verbal group minus the finite in the mood element. The predicator itself is thus nonfinite, and there are non finite clauses containing a predicator but no Finite element.

A complement is an element within the Residue that has the potential of being Subject but is not. It is typically realized by a nominal group. By this definition, it resembles the definition of the object in traditional terms. There is one exception of this general principle: that is, the attributive complement after verb 'to be' as in Obama's clause "It is not true", where 'true' is a complement. 
It is typically realized by an adverbial group or a prepositional phrase. The typical order of elements in the Residue is: Predicator ${ }^{\wedge}$ Complement ${ }^{\wedge}$ Adjunct(s). However, an adjunct or a Complement may occur thematically; this does not mean that it is a part of the Mood.

Modal Adjuncts are classified into two types: (1) mood adjuncts: they are so called because they are closely associated with the meanings constructed in the mood system: those of polarity (yes, no, not), modality (probably, possibly, perhaps), temporality (still, already, just) and mood (clearly, almost, nearly); (2) comment adjunct: they express the speaker's attitude towards the proposition as a whole. They have a very significant function in the clause separated from the rest of the clause by commas, such as 'Fortunately' in Carter's statement

"Fortunately, we've had a Republican president to check their excesses with my vetoes."

As realized by circumstantial Adjunct, circumstances "encode the background against which the process takes place" (Thompson, 2004, 109). Circumstances perform a set of functions in the clause as the representation of time, place, cause and manner, etc. Table (1-3) illustrates the English circumstances and their meanings.

Table 0 Circumstances - Adopted from Halliday (1994, P. 150)

\begin{tabular}{lll}
\hline \multicolumn{1}{c}{ Circumstances } & \multicolumn{1}{c}{ Meaning } & \multicolumn{1}{c}{ Probed by } \\
\hline Extent & Distance, duration & 'When?' \\
Location & Place, time & 'Where?' \\
Manner & Means, quality, comparison & 'How?' \\
Cause & Reason, purpose, behalf & 'Why?' \\
Contingency & Condition, concession, default & 'Under what conditions?' \\
Accompaniment & Comitation, addition & 'Who with?' \\
Role & Guise, product & 'What as?' \\
Matter & & 'What about?' \\
\hline \hline Angle & & 'Says who?' \\
\hline
\end{tabular}

\section{Personal pronouns}

Personal pronouns always deserve notice (Fowler and Kress, 1979, p. 201). Linguists distinguish between the roles of the personal pronouns 'I' and 'you' and the other roles of 'he', 'she', 'it' and 'they'. The use of the personal pronouns is said to signify that "the referent is defined interpersonally" (Halliday, 1994, p. 189). SFG pays attention to the use of the personal pronouns 'I' and 'we' and the meanings they convey with respect to the relationship between participants. Fowler and Kress claim that "[t]he simplest 'we' form is 'exclusive' 'we': the writer refers to himself and some other person(s) not including his addressees"(p.201). Such reference includes also the pronouns 'us' and 'our'. Another meaning that can be signified by 'we' is the 'inclusive we'. It implies that the addresser maintains solidarity and intimacy with the listener. The use of the pronoun 'you', on the other hand, is said to measure the speaker's intention to address his/her recipients. As for the third person pronouns, they can be used to imply distance and indirectness.

Thus, the use of personal pronouns is considered as "a key element textually revealing the complex of social relations, particularly in spoken genres" (Halliday, 1994, p.298). Ward (2004) asserts that the use of personal pronouns assigns the 'degree of power or control' over one another.

\section{Methodology and theoretical framework}

The analysis commences by the SFG representation where the interpersonal metafunction of the Hallidayan Systemic Functional Grammar (Halliday, 1994) is used as the major analytical framework. This lexico-grammatical theory is a self-contained system, trying to explain why language is the way it is. The theory perceives language as a network of options from which language users make selections. The system networks are fed into the computer software where human annotation takes place. After annotation, SFG-based statistics are queried for features that satisfy the needs of the research questions. In this study the software UAM CorpusTools developed by Mike O'Donnel is utilized. Finally, the results are analyzed to see how SMS senders communicate with their target audience.

\section{Analysis and discussion}

A crucial requirement to capture the market of mobile communication is the fast communication between the mobile network operators and the current and prospective customers. This can take place through various communicative channels, one of which is the texts messages. The analysis of the interpersonal metafunction of the SMSs reveals the exchange that takes place between participants of such kind of discourse. The choice of tense, mood type and the pronominal references reflect how service providers opt to interact with their recipients in the process of giving or demanding. 


\subsection{Tense Choice}

There are various factors that determine tense choice especially when language is intended to convince the receiver through a short chunk. Tense in a given discourse is chosen according to the purpose of the message. Hintz (2007) claims "the functions of tense in discourse....are often not limited to locating events in time"(p.122). It can be seen from the following table that the present tense over-rules.

Table 2

\begin{tabular}{llll}
\hline TENSE-TYPE & Mobinil & Vodafone & Etisalat \\
Present & $100.00 \%$ & $80.50 \%$ & $100.00 \%$ \\
Past & $0.00 \%$ & $19.50 \%$ & $0.00 \%$ \\
\hline
\end{tabular}

The table shows that the present tense dominates the language used by the companies especially Mobinil and Etisalat. The following examples illustrate this:

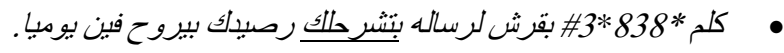

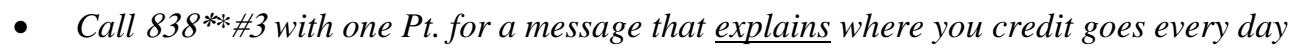

$$
\text { • استنتع ب } 500 \text { وحده فيكس تستخدهم زي ما انت عايز }
$$

- Enjoy 500 felix unit to use as you like

- Everytime you recharge with 10 LE you will have 20 free minutes

$$
\text { • عل ما تشحن ب } 10 \text { جنبه هتاخد } 20 \text { دقيقة مجانية }
$$

$$
\text { • موبينيل بتقدملك سهل طريقة للتحويل كلم 7\# و حول رصيد }
$$

- $\quad$ Mobinil offers the easiest way to transfer, call \#7\# and transfer the credit

The previous examples highlight the reasons for the use of the present tense. Verbs in present tense such as 'explains', 'like', 'recharge', and 'offers', promote the subscription of new clients who many want to have the same 'current present' experience. Continuity and permanence of the returning benefits make the present tense the best choice for the messages sent to clients who, in turn, seek a lot of benefits. Another reason for such use may be ascribed to the need of the sender to assure that what the receiver witnesses is an evidence and fact of his benefit. Such use may help in convincing the receiver of and make them believe in the truth of the complement.

Although the past tense may "usually involves imparting less information than the use of the present"(Riddle, 1978, 120 ), service providers may manipulate it to imply some meanings indirectly. As seen in table (2) the past tense is used with a percentage that has not exceeded $20 \%$ of the whole corpus. Vodafone SMSs use the past tense in some examples. If compared to the simple present tense, the low percentage of the past tense still has significance in convincing the receiver. The following examples use past tense to show that the processes of 'promotion' or 'winning' are complete processes not liable to any changes.

$$
\text { • العرض بِأ الحق و اشترك بخصم } 50 \text { \% }
$$

- The offer began, hurry up and subscribe with 50\% discount

$$
\text { الو عمل اللي متعملث مع الو اوبسن استمتع بمجموعة اضافات. }
$$

- $\quad A L O$ did what had never been done. With ALO options enjoy many additional services.

$$
\text { امبارح بيوم } 3 \text { اكتوبر كان معاك } 7.86 \text { ج و صرفت في شحن و تحويل رصيب. }
$$

- Yesterday was 3rd of October, you had 7.86 and you transferred credit ....

The verbs 'began' and 'did' indicates that the actions already started and that the client is ready or even in a hurry to get the 'prepaid' services offered by the company. Other messages may use verbs in the past tense giving the clients past account statements which may reflect transparency and where the clients' money goes. The third example exemplifies this.

\subsection{Mood Types}

An interesting finding in the analysis of the given corpus can bee seen in the approximate resemblance of the use of both the declaratives and the imperatives. The following table shows that the average use of declaratives is $50.3 \%$ while the average use for imperatives is $49.7 \%$

Table 3

\begin{tabular}{lllll}
\hline \multicolumn{1}{c}{ Mood type } & Mobinil & Vodafone & Etisalat & average \\
Declarative & $40.60 \%$ & $52.20 \%$ & $58.10 \%$ & $50.30 \%$ \\
Imperative & $59.40 \%$ & $47.80 \%$ & $41.90 \%$ & $49.70 \%$ \\
Interrogative & $0.00 \%$ & $0.00 \%$ & $0.00 \%$ & $0.00 \%$ \\
\hline
\end{tabular}


Service providers vary in terms of their use of declaratives. It can be seen that the both Etisalat and Vodafone prefer declaratives more than Mobinil does. The reason why Vodafone and Etisalat opt for declaratives more than imperatives may be ascribed to the need to send a lot of information in the short messages, declaratives in this context are seen to be purposefully used to acclaim a winner, state a status, or congratulate a user. This may be represented in the following examples:

- 0.51 Pt. had been deducted from you credit as tax fees

$$
\text { تم خصم } 0.51 \text { جم من رصياكك رسوم ضربية دمغة (موبينيل) }
$$

$$
\text { تم اضافة } 102 \text { نقطة صالحة حتى 29-2016-9 لديك الان } 630 \text { نقطة في رصيد النقاط الخاص بك }
$$

- 102 points had been added till 29-9-2016. you have now 630 point in your point credit

$$
\text { ا'تصالات عاملة مفاجأ بوم } 25 \text { ديسمبر و انت اول واحد بيرفها }
$$

- Etisalat have a surprise on the 25th of December and you are the first one to know it.

$$
\text { • مثمن الكارت و رصيذك أصبح } 50.1 \text { جنبه (فود/فون) }
$$

\section{- $\quad$ You card had been recharged and you have now 50.1 LE.}

The previous examples, among others, are helpful in providing the clients of the required informtions. Even though these declaratives are short chunks, they may answer the clients' questions or inform the users of new services and offers and similar digital products.

As it is vital for service providers to give information, it is also important to increase their profits by demanding from the receivers.

It can be observed that imperatives are used equally with declaratives. It is undeniable that imperative clauses can be manipulated by service providers to get the audience to follow their embedded instructions. This is claimed in the essential function of SMS as it “...provides a stronger call to actions” (Haig, 2002 p.11)

Although imperatives seem to give an authoritarian impression, the messages are seen to be preceded by a declarative clause that includes information beneficial to the user. The following examples show how the two-clause messages empower the hearers and push them forward to do something of their benefit which of course is in return is beneficial to the service provider.

$$
5 \text { دقبقة لارقام فودافون لمده } 7 \text { ابام، للاشتراك كلم }
$$

- $\quad$ Five minutes for Vodafone number for 7 days, to subscribe call \#757*10*

$$
\text { حصريا من موبينيل هتقدر تنزل كول تون اغاني اراب ايدول فقط كلم } 999 \text { ب } 50 \text { قرش للاقيقة }
$$

- Exclusively from Mobinil you can download Arab Idol call tones. Only call 999 with 50 Pt.

Such combination of declarative-imperative messages can be seen as a useful linguistic repertoire creating a two-waycommunicative environment. This in turn can help shortening the distance between the sender and the receiver making the clients trust the company and also convinced that they are appreciated by it.

\subsection{Adjuncts}

The use of adjuncts in any type of discourse varies in its importance from one type of discourse to another. It can be seen from table (4) that the circumstantial adjuncts have over ruled comment adjuncts with a percentage exceeding

Table 4

\begin{tabular}{lr}
\hline ADJUNCTS-TYPE & Percent \\
Comment-adjunct & $9.5 \%$ \\
Circumstantial-adjunct & $90.5 \%$ \\
\hline
\end{tabular}

As indicated in table above, it can be noticed that the sender opts for the use of the various circumstantial adjuncts to describe the products they have from different perspectives such as time, place, manner, etc.

Reference to these elements is helpful in answering a number of questions depending on the intention of the sender and the targeted audience. It is also important to describe the services and nature of the products. The following table shows the distribution of such elements in the given corpus:

Table 5

\begin{tabular}{lr}
\hline CIRCUMSTANTIAL-ADJUNCT-TYPE & Percentage \\
Manner & $30.3 \%$ \\
Time & $25.0 \%$ \\
Contingency & $11.8 \%$ \\
Extent & $9.2 \%$ \\
Cause & $7.9 \%$ \\
Accompaniment & $6.6 \%$ \\
Angle & $6.6 \%$ \\
Role & $2.6 \%$ \\
\hline
\end{tabular}


It can be noticed that manner adjuncts are used with a percentage $30.3 \%$ of the total amount of adjuncts. The following examples represent some of such uses.

$$
\text { للاشتراك اتصل ب } 858 \text { مجانا }
$$

- $\quad$ To subscribe, freely call 858

$$
\text { اشحن ب23 جنبه او اكتر و استمتع ب20 دقبقة لمده يومان بيلاش }
$$

- Recharge with 23 LE or more, and freely enjoy 20 minutes for 2 days

In the previous examples the company attempts to use adjuncts which appeals to the clients. The services a positively portrayed to attract a lot of users. The words 'مجانا' and 'بيلاش' are likely to draw clients to the services offered, especially when they are 'free'.

Second in rank is time adjuncts which relate the audience to the temporal reference of the products offered by the sender. For example:

\section{احصل على ضعف رصياك لما تشحن ب 10 جنيه /و اكثر}

- Get the double of your credit when you recharge with 10 LE or more

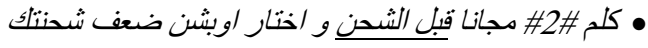

- Call \#2\# freely before recharging and choose the Double Credit option.

- Now, subscribe freely in My Road Service

$$
\text { • الان اشترك مجانا في خدمة طريقي }
$$

The time reference is very crucial in the text messages sent by the company. Time is the currency dealt with by mobile operators. Things are based on other things. This entails that some actions are supposed to be taken before gaining the benefits offered. In this case temporal adjuncts take place. Also senders may use adverbials which indicate the time when the services are available. The time adjunct 'now' for instance indicates that what the receiver is waiting for, in now available.

The reason why manner and time circumstantial elements outnumber the types of adjuncts is based on the importance of information conveyed by the mobile operators to the audience, regarding the manner of the product and the time in which the product becomes available.

Conditional clauses also occupy a considerable sum in the given data. Contingency adjuncts are seen in the following instances:

$$
\text { لو عايز تلغي خدمة رسابل العروض من اتصالات /بعت رسالة فاضية ل829 }
$$

- If you want to cancel the promotion messages from Etisalat send an empty message to 829

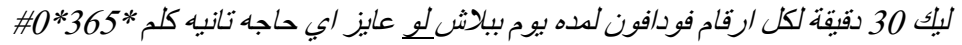

- You have 30 minutes to all Vodafone numbers for two days. If you want anything else call \#0*365*

$$
\text { مدكن تكسب اوضه و مطبخ لو جدعت كلمة اوضه للمزيب كلم *\#4 او اتصل ب } 800
$$

- You can win a room and a kitchen if you collect the word 'room'. For more information call *4\# or call 880

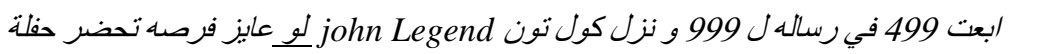

- Send 4999 in a message and download John Legend call tone if you want to attend the party

These examples are good representation of the gains that are conditioned by another action taken by the client himself. This two-clause declarative creates an atmosphere of mutual benefit or exchange between the company and the clients.

Extent adjuncts revolve around the duration in which the digital products advertised are offered for how long. The following examples show how senders exploit such adjuncts:

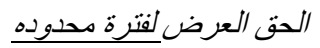

- Hurry up the offer is available for a limited time

$$
\text { تم اضافة } 102 \text { نقطة صالحة حتى 29-916-9 }
$$

- 102 point are valid till 29-9-2016

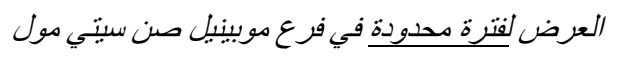

- The offer is valid for a limited time in Mobinil branch in Sun City Mall

Because the main interest of the companies to draw a large number of clients in a short time, extent adjuncts are used to limit the time span available for the clients to subscribe for a certain service or limit the availability of of some products. The adjuncts 'for a limited time' and 'till 29-9-2016' are good examples for such significant use. 
Cause, accompaniment and angle are three adjuncts used with nearly the same percentage of usage which ranges from $6.6 \%$ to $7.9 \%$. Their use has discursive implications. The following examples show the mass benefits that users will gain fro the offered products.

$$
\text { • حصريا مع موبينيل و بي تك اشتري لاب توب و اشترك في باقة اون لاين }
$$

- Exclusively, with Mobinil and B.Tech you can buy a laptopb and subscribe to Online Bundle.

$$
\text { كل اعادة شحن بمكافاه }
$$

- $\quad$ Every recharge process goes with a reward.

In this example, the adjunct shows that benefit will be gained in accompaniment with the advertising company. The statement indicates that it is with Mobinil and B.Tech that you can buy a new laptop. In the second example, the statement shows that each credit recharge is accompanied with a reward. In similar statements such accompaniment adjuncts are used with positive implications.

Cause adjunct are also used in this context to justify the reason for the advertised offers. The client always has a reason to do a certain action and it is a good quality reason. The following example illustrate the point.

$$
\text { بناءا على تعلبيات الجهاز القومي للاتصالات كلم } 367 \text { الان لتحديث بياناتك }
$$

- According to NITRA call 367 now so as to update you data.

Returning again to Table (4), it can be observed that despite their low frequency, comment adjuncts are also used to perform the modal function of expressing attitudes and judgments and convince the user that he is about to experience something beneficial for him. For instance,

$$
\text { ارق التهاني بمناسة /عياد رأس السنة و الدولد النبوي الثريف }
$$

- Congratulations for the New Year and the Prophets' Birthday

$$
\text { حصريا مع موبينيل و بي تك اشتري لاب توب و اشترك في باقة اون لابن }
$$

- $\quad$ Exclusively, with Mobinil and B.Tech you can buy a laptopb and subscribe to Online Bundle.

$$
\text { مبروك لديك صلاحبة مدى الحياة }
$$

\section{- $\quad$ Congratulations, you have a lifetime validity}

Comment Adjuncts as claimed by Halliday (1994) “express the speaker's attitude either to the proposition as a whole or to the particular speech function" (p.129). Such use of comment adjuncts is helpful in shaping the receivers' minds with the point of view and the gains returning to the mobile users.

\subsection{Pronouns}

Personal pronouns always deserve notice (Fowler and Kress, 1979, p. 201). Linguists distinguish between the roles of the personal pronouns in general and the 'I' and 'you' in particular. The use of the personal pronouns is said to signify that "the referent is defined interpersonally" (Halliday, 1994, p. 189). SFG pays attention to the use of the personal pronouns 'I' and 'we' and the meanings they convey with respect to the relationship between participants.

The use of the personal pronouns in the data at hand is very indicative. Except wit $h$ a few instance where the first plural person pronoun (-na) 'our', almost all the references in the analysed SMSs are represented in the 2nd person voice. Regardless of the process type, the recipient seems to be a second person. This creates an atmosphere of intimacy and portrait the image of having a dialogue between the sender and the receiver of the message. The following examples show that:

$$
\text { عميلنا العزيز للاستفسارات عن الخدة اتصل ب } 333 \text { مجانا }
$$

- $\quad$ Our dear client for inquiries about the service call 333 freely

$$
\text { عروض ممبزة معبزة للعملاء المدبزين اطلب *011 \#بيلاش و شوف بنفسك }
$$

- $\quad$ Special offers to the special cliens call *011\# and see it yourself

- $\quad$ This week's reward goes only for you.

$$
\text { مكافأه هذا الاسبوع من اتصالات عشانك انت بس }
$$$$
\text { انت سعبي الحظ مع اتصالات ليك } 200 \text { جنبه رصيد هدية }
$$

- $\quad \underline{Y o u}$ are lucky with Etisalat you have 200 LE credit as a gift

Biber and Conrad (2009) claim that both the first and second person pronouns are commonly found in the languages used ion SMSs. "This reflects the primary focus on the sender and receiver" (p.207).

The current analysis finds that the use of the second person pronoun is aimed at orienting the receiver of the benefits gained not a thing imposed on him. The sender is anonymous where no social relations are attained so the directness of the second person is in favor of the receiver to the sender especially in such context where immediate response is not a must. 


\section{Conclusion}

Text Messaging has a very wide reach, especially when they are sent by the mobile operators which have access to millions of its subscribers. Such large scale of audience may allow the company to advertise and prompt marketing campaigns, regardless of social or economic standard of the clients.

It is clear from the analysis carried out that the grammatical choices are intended to communicate some kind of interpersonal messages between the sender (service provider) and the receiver (Mobile user). Such interpersonal relations are manifested through the exploitation of the grammar of Mood, tense and pronouns.

Mood choice indicates how the sender attempts to sustain a relationship with the receiver. Balancing between the declaratives and the imperatives, senders manage to create an intimate dialogic style avoiding any authoritarian impression on the senders.

A similar effect is achieved by the use of the second personal pronouns which help managed to overcome the selfreferencing and self-distancing at the same time. In fact, the flexibility of the use of text messaging allows the senders to be creative in creating a conversational or dialogic atmosphere between the company and the receiver which inturn returns to be beneficiary for both sides.

\subsection{Further research}

It is highly recommended to study other means of technological exchange that takes place using the Arabic language.. It could also be beneficiary to observe the impacts of using SMS for commercial purposes and marketing bargains in various cultures. Further research can also be directed to a comparison between Short message techniques in Arab and western cultures. Different linguistic repertoire has to be investigated as used in computer-mediated discourse. Scholars could also explore the cognitive and affective componets of the language used in computer mediated exchanges.

\section{References}

Biber, D. and Conrand, S. (2009). Register, Genre, and Style.UK: Cambridge University Press.

Butler, C. (2003). Structure and Function: A Guide to Three Major Structural- Functional Theories. USA: John Benjamin's Publishing.

Cronin, A. (2007). Computer-Mediated Communication and Negotiation: Effects of media and Power on Relationship Development (Doctoral dissertation). Retrieved from Proquest (3277486).

Eggins, S. (2004). An Introduction to Systemic Functional Linguistics. London: Continuum Publishing International.

Fairclough, N. (1989). Language and Power. USA: Longman.

(1995). Critical Discourse Analysis: The Critical Study of Language.

USA: Longman.

. (1996). Technologisation of Discourse. In Carmen Rosa and Malcolm Coulthard (Eds.), Texts and Practices. (pp. 71-83). London: Roultedge.

(2003). Analysing Discourse: Textual Analysis for Social Research. London: Routledge.

(2005). Peripheral Vision: Discourse Analysis in Organization Studies: The Case for Critical Realism. Organization Studies, 26 (1), 915-939.

Fairclough , N., \& Wodak, R. (1997). Critical Discourse Analysis. In Teun van Dijk. (Ed.), Discourse Studies: A Multidisciplinary Introduction. Volume 2. (pp. 258-283). London: Sage Publication.

Fowler, R. and Kress, G. (1979). Critical Linguistics. In R. Fowler, B.Hodge, et al (Eds.). Language and Control. (pp.185-213). London: Routledge and Kegan Paul.

Frehner, C. (2008). Email, SMS, MMS: The Linguistic Creativity of Asynchronous Discourse in the New Media Age. UK: Die Deutche Bibliothek

Haig, M. (2002). Mobile Marketing: The Message Revolution. UK: Biddles.

Halliday, M. A. K. (1982). The De-automatization of Grammar. In J. Anderson, Ed., Language Form and Linguistic Variation, (pp.129-159). Amsterdam: John Benjamins.

Halliday, M. A. K. (1994). An Introduction to Functional Grammar. USA:Oxford University Press.

Halliday, MAK. \& Hasan, Ruqaya. (1989) Language, Context, and Text: Aspects of Language in a Social Semiotic Perspective. London: Oxford University Press.

Halliday, M.A.K. \& Matthiessen, M.I.M. (2004). An Introduction to Functional Grammar. USA: Oxford University Press.

Halliday, M.A.K \& Teubert, Wolf. (Eds). (2004) Lexicology and Corpus Linguistics. USA: Continuum International Publishing.

Johnstone, B. (2008). Discourse Analysis. USA: Blackwell Publishing.

Herring, S. et.al. (2013). Introduction to the Pragmatics of Computer-Mediated Communication. In Susan Herring et.al (Eds). Pragmatics of Computer-Mediated Communication. (pp.3-32). Germany: Walter du Gruyter

Herring, S. (2013). Discourse in web 2.0: Familiar Reconfigured and Emergent. In Deborah Tannen and Anna Marie Trester (Eds.). Discourse 2.0: Language and New Media. (pp. 1-26). USA:Georgetown University. 
Howarth, D. and Stavrakakis, Y. (2000). Introducing Discourse Theory and Political Analysis. In David Howarth and Yannis Stavrakakis et al. (Eds.), Discourse Theory and Political Analysis: Identities, Hegemonies and Social Change. (pp. 1-23). USA: Manchester University Press.

Humphreys, L. (2007). Mobile Sociality and Spatial Practice:a Qualitative Field Study of New social Networking Technologies (Doctoral dissertation). Retrieved from ProquestUMI. (3271770)

Ling, R. (2004). The Mobile Connection: The Cell Phone's Impact on Society. USA: Morgan Kaufmann publishers.

Ling, L. (Eds) (2014). Innovative Methods and Technologies for Electronic Discourse Analysis.USA: IGI Global

Moore, L. and Craig. E. (2010). Relationship Development and Maintenance in a Mediated World. In Jung-ran Park (Ed.) Interpersonal Relations and Social Patterns in Communication. (pp. 77-99).USA: IGI Global 2010.

Moore, J. D., \& Wiemer-Hastings, P. (2003). 12 Discourse in Computational Linguistics and Artificial Intelligence. In Handbook of Discourse Processes, Graesser, A. C., Gernsbacher, M. A., \& Goldman, S. R. (Eds.) (pp. 439-478). Mahwah, NJ: Lawrence Erlbaum Associates.

Moutaouakil, A. (1989). Pragmatic Functions in a Functional Grammar of Arabic. Holland: Foris Publications.

Parks, M. R., \& Floyd, K. (1996). Making friends in cyberspace. Journal of Communication, 46(1), 80-97

Riddle, E. (1978). Sequence of Tenses in English. USA: University of Illinois Press

Rodney, J. (2012). Discourse, Creativity and Technology. In Jones Rodney (Ed.). Discourse and Creativity. (pp.165189).USA: Routledge.

Stavrakakis, Y. (2000). On the Emergence of Green Ideology: The Dislocation Factor in Green Politics. In David Howarth and Yannis Stavrakakis et al. (Eds.), Discourse Theory and Political Analysis: Identities, Hegemonies and Social Change. (pp. 100-118). USA: Manchester University Press.

Scollon, R. (1998). Mediated Discourse as Social Interaction: A Study of News Discourse.USA: Routledge.

Segerstad, Y. (2006). Language in SMS-a Soci-linguistic View. In R. Harper and L. Palen, A. Taylor (Eds.). The Inside Text: Social, Cultural and Design Perspectives on SMS. (pp.33-53). USA: Springer.

Sieloff Magnan, S (Ed). (2008). Mediating Discourse Online. USA: John Benjamin Publishing Company

Spilioti, T. (2011). Beyond Genre: Closings and relational work in text messaging. In Crispin Thurlow (Ed.). Digital Discourse: Language in the New Media. (pp.67-128). USA: Oxford University Press.

Steiner, E. (1991). A Functional Perspective on Language, Action, and Interpretation: An Initial Approach with a View to Computational Modeling. USA: Mouton de Gruyter.

Tag, C. (2012). Discourse of Text Messaging: Analysis of SMS Communication.UK: Continuum publishing.

Teich, E. (1999). Systemic Functional Grammar in Natural Langugae Generation: Linguistic Description and Computational Representation. London: Continuum Publishing Company.

Thompson, G. (2004) Introducing Functional Grammar. London: Oxford University Press.

van Dijk, T. (1996). Discourse, Power and Access. In Carmen Rosa and Malcolm Coulthard (Eds.), Texts and Practices. (pp. 84-103). London: Roultedge.

(1997a). The Study of Discourse. In Teun van Dijk. (Ed.), Discourse Studies: A Multidisciplinary Introduction. Volume 1. (pp. 1-34). London: Sage Publication.

(1997b) Discourse as Interaction in Society. In (Teun A. van Dijk Ed.), Discourse as Social Interation.

Discourse Studies: A Multidisciplinary Introduction. Volume 2. London: Sage Publications.

. (1998). Ideology: A Multidisciplinary Approach. London: Sage Publications.

. (2002) Multidisciplinary

CDA: a Plea for Diversity. In Ruth Wodak (Ed.) Methods of Critical Discourse Analysis. (pp. 95-119). London: Sage Publications.

Ward, M. (2004). We have the Power - Or do We: Pronouns of Power in a Union Context. In Lynne and Young and Claire Harrison. (Eds.), Systemic Functional Linguistics and Critical Discourse Analysis: Studies in Social Change. (pp. 281-295). NewYork: Continuum.

Wodak, R. (2002). What CDA is about: A Summary of its History,Important Concepts and its Developments. In Ruth Wodak and Michael Meyer (Eds.) Methods of Critical Discourse Analysis. (pp. 1-12). London: Sage Publications.

\section{Key terms and definitions}

SMS: Short Messaging service allowing users to exchange short informative chunks

Computer-Mediated Discourse: A type of discourse exchanged where computerized means is the medium of communications

Mobile Service Provider: The Mobile operator provides the mobile services such as voice call, SMS, Mobile Data

Mood: In SFG terms, mood refers to the combination of Finite and Subject whether declaratives, interrogatives or imperatives

Tense: The time in which the action happens reflected in the Finite

Pronouns: An anaphoric reference substituting the nominal referents 